\title{
飛行場管制用航空機運航管理システムの検討と試作
}

\section{塩 見格一* \\ Designing and Prototyping of Airport Traffic Management System}

Kakuichi SHIOMI

\begin{abstract}
Airport Traffic Management System based on Object Oriented Data Base System is prototyped. The prototyped system consists of four engineering workstations connected by network. By using this system airport tower controllers can access all information necessary for airport traffic control and can exchange the information among them.

As the results of the simulation carried out under the virtual reality environment of the airport control tower, all instruction of airport traffic control can be done by only using mouse in this system.

And each console has been realized the compatibility of the console that will be used to access controller $=$ pilot data link.
\end{abstract}

\section{1. 研究の背景}

今日の航空管制業務は航空機運航票を使用して行われている。航空機運航票は、管制対象である航空機 の運航計画等運航に係わる情報を定められた書式により記載した紙片であり、単に運航票或はストリップ とも呼ばれている。

航空管制業務には、レーダーにより航空機を監視しながら行う、航空路及び出発進入空域（ターミナル 空域）に対するレーダー管制業務と、管制官が肉眼で直接に航空機を監視しながら行う飛行場管制業務と があるが、何れの管制業務においても、書式等に差異はあるものの、現状では紙の運航票が使用されてい る事実は同様である。

管制業務の遂行において、管制官は自らの管制する航空機の運航票を管理し、航空機の管制状況に対庇 して、それに対応する運航票に必要な書き込み等を行い、また臨席の管制官に航空機を移管する場合には、 合わせてその運航票を手渡し等により移管する。原則的に、管制対象である各航空機に対して、有効な運 航票は 1 枚しか存在しないように管理されており、意味論的には、航空機とその運航票は管制官にとって 等洒である。

本研究は、上記のように、今日の航空管制業務を進める上で重要な役割を果している航空機運航票を、 正確には運航票に記載される航空機運航情報を、ネットワークにより接続されたコンピュータ・システム により管理することを可能とする航空機運航管理システムの開発に係わるものである。

以下、研究の目的として、今後の航空管制業務の効率化において航空機運航管理システムに要望される 機能を述べ、また 4 章以下では、それら要望されている機能に対して、試作システムにより実現されてい る機能、その機能を実現するために行った検討、及び実現するための手法等について紹介する。

\section{2. 研究の目的}

現状の航空管制業務は、管制官とパイロットとの間の無線電話による音声通信により行われている。管 制官は、パイロットからの管制要求を受け、その航空機の状況をレーダーや目視により確認し、その都度

* 正会員 運輸省電子航法研究所（テ181 東京都三鷹市新川6-38-1） 
適切な管制指示を発出する。

しかし、近年の世界的な航空交通量の増大は、管制官ハパイロット間の通信を音声のみによっては最早 タイムリーな管制が困難である程に増大させている。また、発展途上国における航空交通の発展等により、 航空需要の増大が、今後はより急速に進むことが予測されており、より処理容量の大きな管制官＝パイロ ット間の通信手段の早急な実現が求められている。

現在、上記要求に対応するために、管制官＝パイロット間データリンクの実現についての検討が進めら れており、空地データリンク（ATN）の評価試験等が実施され、その仕様が維められようとしている。

実に、航空通信のデータリンク化は、将来的な航空需要の増大に対応するために、歴史的に必然のこと と考えられる。しかし、データリンクの両端に存在するのは、データリンクの導入によっても変わること のない人間である管制官とパイロットであり、データリンクの導入が彼らの業務量の増大を招くものであ れば、航空需要の增大に対応寸ることにはならない。

本研究において試作した航空機運航管理システムは、データリンク導入後の管制官側インタフェース・ システムに要求される機能をシミュレーションにより探ろうとするものである。

試作システムは、運航票に記入され提示されている各航空機の運航情報をCRT上に表示し、この表示部

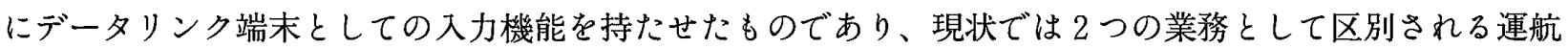
票の管理業務とパイロットとの通信業務（パイロットからの管制要求受信業務とパイロットへの管制指示 発信業務) を、一連・一体の管制業務として行うための管制業務機器のプロトタイプとして試作した。

即ち、「紙の運航票に管制状況をボールペンで記入しながら、またデータリンクへの入力のためにCRTを 見ながらキーボードやマウスを使用する必要がある」環境に対し、「CRT上の運航情報をマウスで処理する ことが直ちにデータリンクへの入力となり、データリンクを通じてのパイロットからのメッセージが直ち に運航情報の管理・更新を実現する」環境を実現するための管制業務機器の開発を目的として、本システ ムの検討及び試作を行った。

\section{3. 飛行場管制業務}

現在の大規模な空港における飛行場管制業務は、夫々に役割分担された 4 人の管制官、副管制官 (FD： Flight Data，管制塔外部の管制機関との調整等を行う管制官)、管制承認伝達管制官 (CD：Clearance Delivery, パイロットに管制承認の伝達等を行う管制官)、地上管制官 (GC：Ground Control, 航空機の地 上走行及び空港面の車両の移動を管制する管制官)、飛行場管制官 (LC：Local Control, 航空機の離発着 を管制する管制官）が連係して進めている。

航空機運航票は、これら 4 人の管制官の間で相互に受け渡しが行われており、各管制官は自分の管理す る運航票に対応する航空機に管制指示を行い々の内容に対応した書き込み等を逐次運航票に行っている。 自らの担当する管制業務が完了した航空機については、その運航票を次席の管制官に渡し、パイロットに 対しては、これに対応する周波数変更が指示される。

なお、管制官からパイロットに伝えられる管制指示は、現状ではVHF帯を使用した音声通信により行わ れており、各管制官は定められた周波数の音声通信チャンネルを1つ以上有している。

図 1 は現在飛行場管制に使用されている運航票の書式を示したものであり、出発機の管制における運航 票の流れは図 2 に示すとおりであり、到着機については図 3 のとおりである。

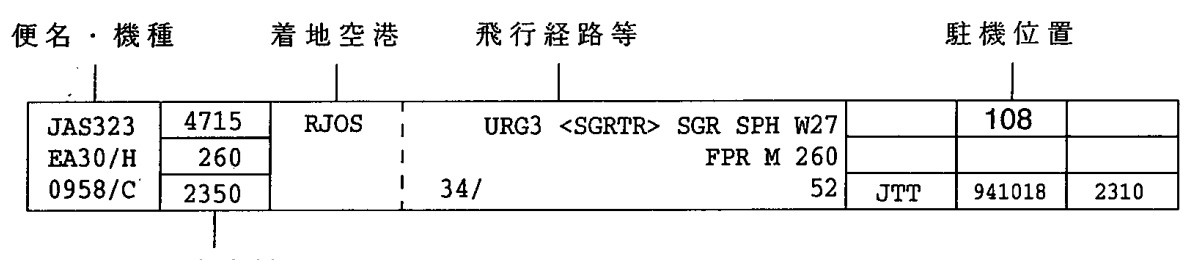

出発時刻

図 1 飛行場管制業務に使用されている運航票の書式 


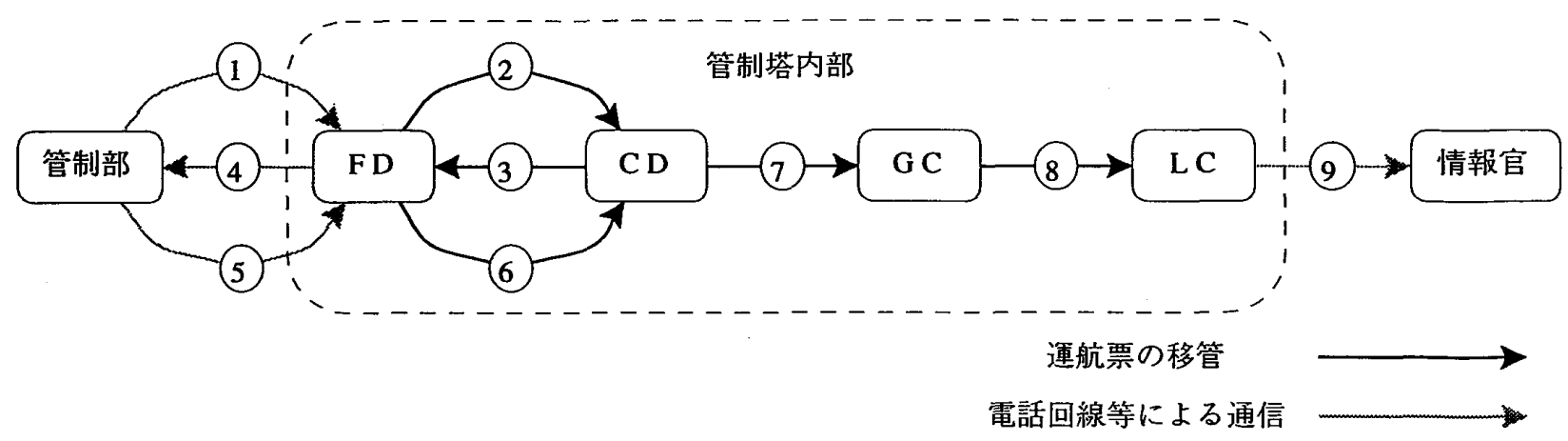

図 2 出発機の管制にょける運航票の流れ

(1) 管制部から運航計画を受信し運航票を発行

(2) 移管

(3) 駐機位置を確認し管制要求

(4) 管制要求

(5) 管制発出

(6) 移管

(7) 管制伝達後移管

（8）地上走行指示後滑走路手前で移管

(9) 離陸確認後移管

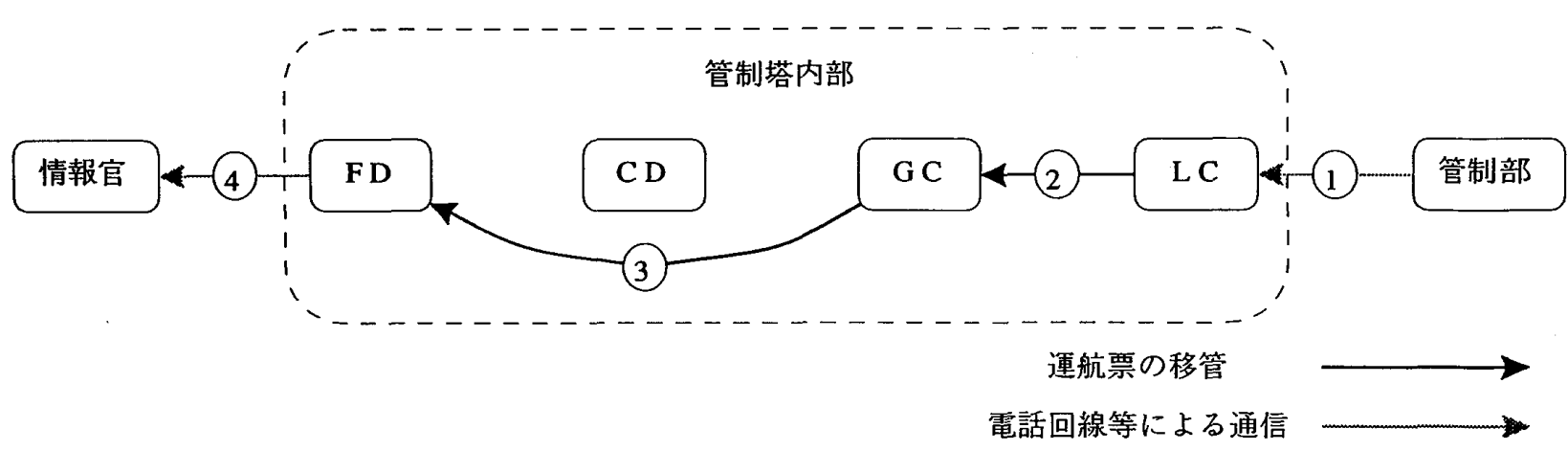

図 3 到着機の管制における運航票の流れ

(1) 到着機の運航票を発行

(2) 着陸後滑走路から出た段階で移管

(3) 駐機位置への地上走行を指示した後移管

(4) 到着を確認して連絡

\section{4. 試作システム}

航空機運航管理システムとして、以下のように、飛行場管制業務を行う 4 人の管制官の業務に対応させ、 4 台のワークステーションによるシステムを試作した。

航空機運航管理システムは、航空機の運航計画情報を管理するFDP (Flight Data Processor) をサーバ とし、各管制官端末をクライアントとする、サーバ=クライアント型データベース・システムと見ること ができるシステムであり、また、各管制官の間での運航情報の受け渡しにより管制業務が進められていく 点に着目すれば、電子メール・システムや広くはグループ・ウェアの一種として捉えることも可能なシス テムである。

ただし、ある航空機に関する情報は、同時には 1 人の管制官によってのみ变更・処理が可能となってい る必要がある点、またどの管制官にも管理されていない航空機が存在する状況は許されない点等が一般的 
なデータベース・システムとは異なっており、実時間の管制業務に対応するだけの応答性等が要求される 点が電子メール・システム等とは異なっている。

また、試作システムにおいては、その機能評洒を管制官参加のシミュレーションによる評洒害験により 行うことが必要であり、その実施を可能とするシミュレーション・シナリオの処理機能を実現している。 なお、シミュレーション・シナリオの処理機能とは、運航計画に従って航空機を発生させたり、管制指示 に従って個々の航空機を地上走行等させる機能である。

このシミュレーション・シナリオの処理機能は、現時点では、シミュレーションの実施に多数のパイロ ット役の要員を要するシステム構成を実現することが困難であったため、シミュレーション実施時にパイ ロット側に要求される航空機の運航に係わる判断を内部プロセスの処理として実現したものである。

4.1 システム構成

本試作システムは、オブジェクト指向型データベース・システムをベースに、各管制官用のクライアン ト・システムをGUI（Graphical User Interface）を有したデータベース端末（クライアント）として構成 した。

シミュレーション機能の実現のために、データベース・サーバをローカル・サーバとしてシナリオ処理 機能を有するものとして作成し、航空機運航管理システム全体として、図 4 に示す形態で飛行場管制シミ ユレーターに組み込んだ。

飛行場管制シミュレーターは、管制塔における管制業務環境を模擬するための視聴覚的な仮想現実感を 実現した装置であり、シミュレーションに参加する管制官は、恰も管制塔にいるかのように飛行場の景観 を見ながら、管制業務の模擬を行うことができるようになっている。

本試作システムは、管制官＝パイロット間データリンクの実用化を想定したシステムであるが、羽田空 港のIII期運用に関して「6. おわりに」に後述する理由により、現状の音声通信により進められる業務形 態にも対応するように、パイロットとの音声通信を模擬するための音声処理機能を付加している。尤も、 音声処理機能は、管制官＝パイロット間データリンクが実現された後も、データリンクとのインタフェー スに有効な機能であり、その開発は、シミュレーションにおいてのみの意義しか持たないものではない。 航空管制業務において音声認識装置は、次世代の入力デバイスとして重要なものの1つである。

4.2 GUIデザイン

飛行場管制業務は、特にGC席及びLC席においては、管制官が自らの肉眼により直接に航空機を監視しな

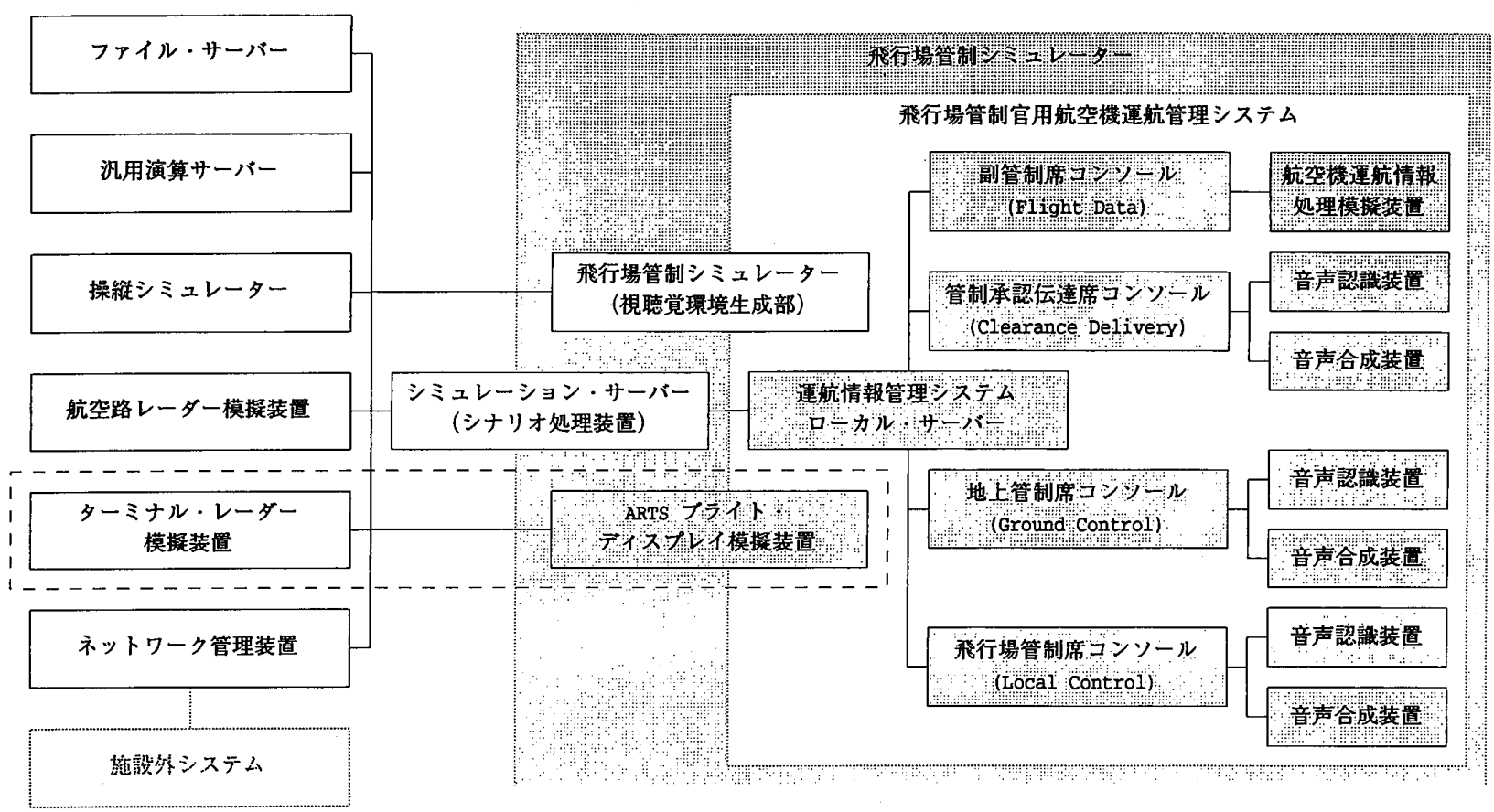

目 4 飛行場管制用航空機運航管理システム構成図 


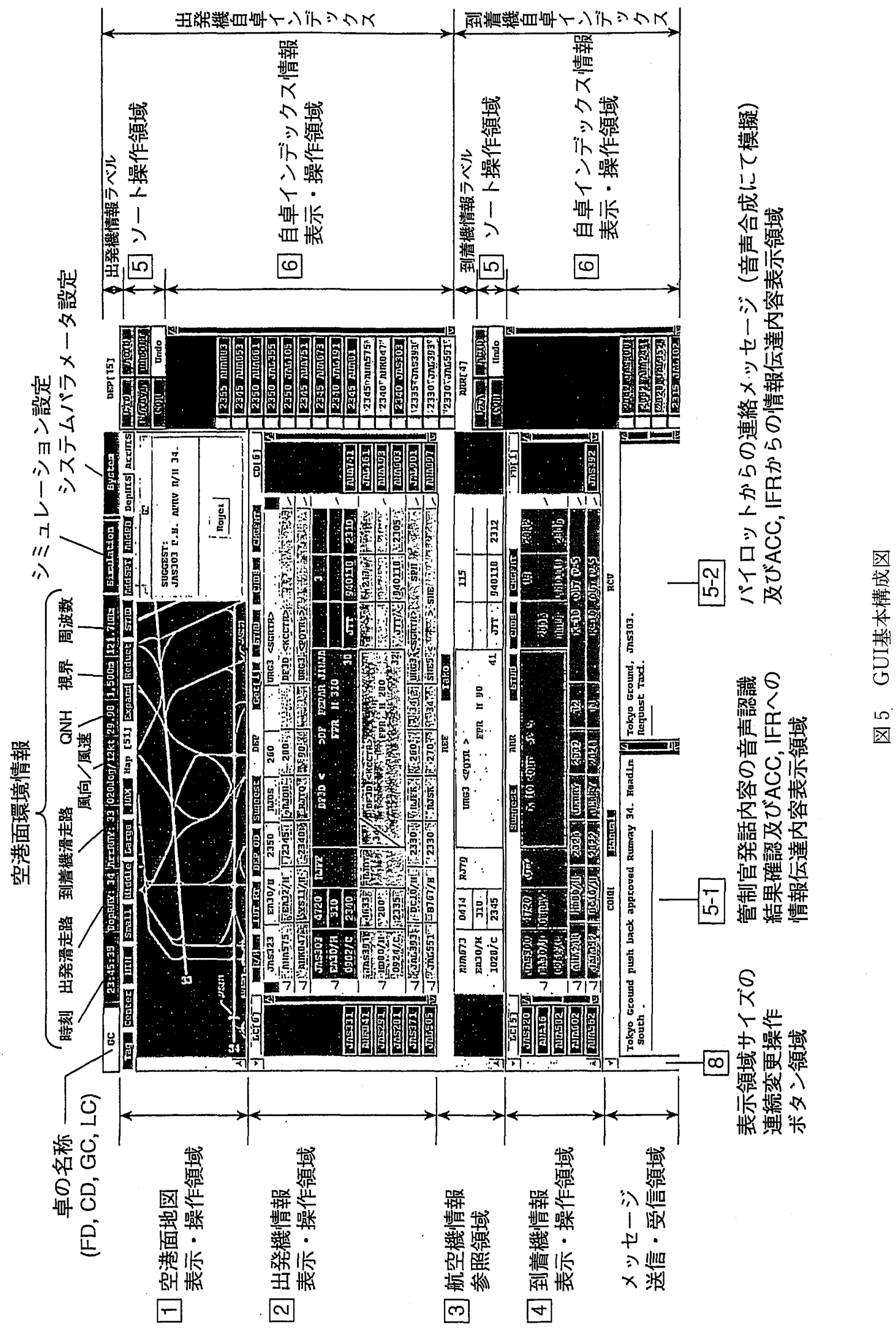


がら行うことが必要な業務であり、その端末装置には、できるだけ手もとを見なくても良いような配慮が 求められている。

これらの要求に対応して、本システムでは飛行場管制業務の遂行に必要な全ての処理をマウスのみによ って実現できるように、GUIデザインを工夫した。各管制席への設置を想定したディスプレイの基本的な構 成は図 5 に示すとおりである。

各機能領域の配置等は、管制官諸氏他の意見を聞きながら試行錯誤により決定し現状に至っている。

配色・配置と疲労度の関係等については、未だ定量的な評価を行っていないが、個人的な差異や熟練度 による影響の少ないように、以下のような点に配慮した。

（1）ディスプレイ上での視点の移動を少なくするため、メニニー・ボタン等は関連する情報の近くに配し た。

（2）航空機の状況を階層的に分類し、配色をカテゴリーに対応させた。

（3）過剩な情報の表示を抑え、各席での業務に基本的な画面構成を共通化した。

(4) タイリング・ウィンドウ形式を採用し、ポップアップ・ウィンドウ等による情報のマスキングが起こ らないようにした。

（5）ある処理を行う場合に複数の方法が可能である場合には、全ての方法を実現した。

また特に本試作システムでは、管制業務がチームワークを重視する業務であることから、各卓において 隣卓の業務状況が判断できる機能等を実現し、更に、航空機の運航情報の受け渡しにょける確認手続きを 明確化するために、運航情報の移管をアニメーションにより表現した。

\section{3 機 能}

本試作システムは、そのシミュレーション機能により、現状の羽田空港における飛行場管制業務をほぼ 完全に再現できるものとなっている。

現役の羽田空港の飛行場管制官に協力を仰いだシミュレーション評価実験においても、飛行場管制業務 に必要な機能は全て、実現の方法やその完成度はともかくとして、実現されていることが確認された。

例えば、主要な機能として以下の機能が害現されている。

（1）自席で管理する各航空機の運航情報を編集したり、並べ換えたりする機能。

（2）移管する航空機に対する運航情報を適切な管制席に速やかに移管する機能。

（3）運航情報や管制承認内容に変更があった場合に、それらを表示する機能。

(4) 臨席の業務状況を参照する機能。

（5） 風向・風速等の気象情報や通信周波数情報等を表示する機能。

上記機能の実現方法や表示形態については、多種・多数の意見を得たが、特に(2)の運航情報を移管する 機能については、その応答性やアニメーションによる表示形態が好評であった。

また、本試作システムは、将来の管制業務の省力化を目的とするものであり、以下のような、管制官の 業務判断を支援する機能のプロトタイプを実現した。

(6) 航空機がプッシュバックする場合の機首方向の適切な選定を指示する機能。

(7) 航空機が地上走行する場合の最短経路の設定に関する機能。

(8) 航空機の出発順位について、これを最適化する機能。

(9) 航空機の離発着間隔について、これを適正化するための機能。

業務判断を支援する機能については、実用化には知識ベースの内容が未だ不十分であるが、今後増大す る航空交通量に対応するためには有効な機能であるとの意見を得た。

音声認識装置による入力は慣熟度に応じて好評であり、システムが話者の発話内容を予測する機能によ り、シミュレーション・シナリオの範囲ではあるがCD、GC、LCの各席において十分実用になる認識率が 達成されな。なお、FD席では、その業務において音声認識装置を使用していない。

音声認識率の定量的な評価については、今後シミュレーション・シナリオのヴアリエーションを增やし て改めて行いたいと考えている。 


\section{5. 今後の計画と見通し}

今日の飛行場管制業務は 4 人の管制官の役割分担の上に成立しているシステム的な業務であるが、この 役割分担は経験的に決められ現状に至っているに過ぎないものである。従って、現状の役割分担が将来的 にも不变であるとは断言できず、また業務に当たる管制官の数についても増減する可能性は大いに残され ていると考えられる。

特に、現状のような業務分担では、管制官の人数を増やすことにより空港の処理容量を増すことは困難 であり、「要員数に比例した処理容量」は実現し得ない。将来的には、より「要員数に比例した処理容量」 の実現可能な方向へ業務形態が変化していくことは十分に考えられる。

本試作システムのソフトウェアは、現時点において可能な限りオブジェクト指向の考え方に添って実現 したものであり、管制業務における役割分担の変更や、管制官の数の増減には柔軟に対応できる構造とな っている。現時点では、サーバを設置することにより、複数の卓に跨がる調整等を行っているが、今後、 サーバ機能の評価を進め、分散管理すべき情報と集中管理すべき情報の分類を高度化し、より柔軟で高機 能なシステムとして再構築する予定である。

またGUI機能については、現状のハードウェアやオペレーティング・システムの有する機能的な制限から、 必ずしもオブジェクト指向とは言えない点を幾つか残しているが、これらの点についても、今後改善を進 めよりポータビリティーの高いシステムとして完成度を向上させていきたい。

\section{6. おわりに}

管制官に対する航空機運航情報の電子表示システムは、世界的に開発が進められているシステムである が、飛行場管制業務において、紙の運航票に代わるシステムは未だ実現されていない。

本試作システムに係わる研究も、我が国の羽田空港III期運用における両面管制において要する、「航空機 運航情報を電子表示により飛行場管制官に提供し、またデータリンクにより管制官の間での受け渡しを可 能とするシステム」の検討から開始したものである。即ち、直接には、羽田空港の両面管制においては運 航票を十数メートル離れた管制塔の反対側にいる管制官に渡す必要があり、この要求に応えるシステムの 開発を目的とした研究が、その後、管制官＝パイロット間データリンクの構想等により、紆余曲折して今 日に至ったものである。

今後の世界情勢によってはどの様な形にまとめ上げることが要求されるのか皆目見当もつかないが、今 回紹介した試作システムは、平成 3 年に研究を開始した航空機運航管理システムから数えて 3 世代目であ り、既に 2 度の大幅な改修を経験しており、今後発生する要求にも十分応え得るだけの柔軟性は実現して いると考えている。尤も、航空管制業務は人命を預かる業務であり、不注意による事故の発生等は許され ることではない。見通しの甘さによる設計ミス等には細心の注意を払っても不十分であることが多いのは、 歴史の教える処であるが、常に最善を尽くしていると言える様努力していくつもりである。

システムの利用者の側においては、コンピュータ等のディスプレイに向かっての作業は、往々にして機 械的に行われる状況に陥りやすく、常に幾分か以上の緊張感を維持することは非常に困難である。「不注意 にクリックしたボタンによりどの様な状況が発生するかが全く未知である様なシステム」にならない様に、 フェール・セーフ、フール・セーフの考え方を取り入れる事等により、今後はより一層の安全性向上を目 的としなければならないであろう。

今後研究を進めるに当たっては、より一般的に、多数の人間と多数の機械か関係し合うシステムにおい て、人間の側の快適さを実現・向上する、システムにおける人間性の確保と保証に係わる、より合理的な マンニマシン・インタフェース実用化を目的としたい。

\section{質 疑 応 答}

山下晃司 (東京商船大学)：GUIの仕様やポインティング・ッールの決定に際して、ぼんな項目をどのよう に検討したか？ また、どのような評価方法によって決定したか？

塩見格一：GUIの仕様は、GUIを構築するプラットフォーム(UNIX、X11R5、Motif、etc)により作成可 
能なものに限定した上で、数種類のレイアウト案を作成し、管制官等の意見を聞いて決定しました。意 見が別れたものについては、その意見の根拠を優劣の判断がつくまで遡り調查して決定しました。 配色等についても同様です。

なお、レイアウト案や配色案、またフォントの大きさ等については、当所で検討・作成したものに加 えて、家電製品のデザインやそのパンフレット等を研究しているシンクタンクに調查・作成の協力をお 願いしました。

ポインティング・ッールの決定は、GUIに要求されるアクションにより決定しました。タッチパネルで は、ドラッグ\&ドロップ等の操作は困難であり、ボタンの形状によっては分解能が不足してしまいます。 トラックボールはドラッグ\&ドロップに両手を要すること等に問題があり、またキーボードを使用する 場合でき矢印キーだけでは全ての操作を行うことはできません。

特に、飛行場管制業務が管制官に管制塔から外を見ていることを要求する業務であることから、手も とを見ずに作業が行えることが重要であり、多数のポインティング・ッールを併用することにも、ポイ ンティング・ツールが手で操作するものである限り問題があります。結果的に、現状では一般的にマウ スが最適であり、ディスプレイの明るさが十分取れる場合には、タッチペンが適当であると結論致しま した。特に、立って業務を行う管制官の場合は、ディスプレイの設置角度にも依りますが、タッチペン が最も使い易いようです。

GUIの仕様やポインティング・ツールを決定する場合、むやみにアンケート調査等を実施すること性有 効ではなく、夫々のGUI案やポインティング・ツールを好ましいと考える代表者を選んで、彼らにお互い を説得するような話し合いをしてもらうことで、本質的な要求が明らかになると考えられます。

第 1 回目の話し合いに依っては結論が得られない場合、プロトタイプを製作して評価試験を行い、第 2 回目の話し合いの場を設けることが必要となります。

疲労度等を評価基準とするためには、極めて長い調查期間が必要であり、短期的な評価では慣熟度に 依る差異に優劣が隠れてしまいます。矓しくて見にくいとか、物理的に重い事等に依る疲労が明らかで ない限り、疲労度に依る評価では、テンキーの配列、マウスのボタン位置等に係わる優劣を決める事は 困難です。 